\title{
REPLY TO COMMENTS ON: COASTAL CAVES IN BAHAMIAN EOLIAN CALCARENITES: DIFFERENTIATING BETWEEN SEA CAVES AND FLANK MARGIN CAVES USING QUANTITATIVE MORPHOLOGY
}

\author{
Willipa J. Waterstrat, John E. Mylroie, Athena M. Owen, and Joan R. Mylroie \\ Department of Geosciences, Mississippi State University, Mississippi State, MS 39762
}

We thank Rane Curl and Bill Mixon for their insight into the statistics of sea cave and flank margin cave morphometry.

We agree that the data are not normally distributed, which puts the results of Waterstrat et al. (2010) into question as use of the Student T-test would be then inappropriate. We agree with Curl's attempt to normalize the data with a log transformation, and the data certainly are closer to normal than they were before the natural log transformation. However, we do not agree that the data are now normal. The log transformed data fail the Anderson-Darling test for normality $(p=0.026)$, and the Shapiro-Wilk test for normality $(\mathrm{p}=0.018)$. This still invalidates the use of the Student T-test as it assumes normality. However, when we conduct the Wilcoxon-Rank Sum Test (the non-parametric equivalent of the Student Ttest) with the natural log transformed $\mathrm{A} / \mathrm{P}$ ratios, we find that the Flank Margin Caves and San Salvador Sea Caves are not significantly different $(\mathrm{p}=0.457)$, as Curl noted using the Student T-test. Further work needs to be done to confirm or reject the use of the various other ratios discussed in Waterstrat et al. (2010).

To clarify Curl's statement about the use of speleothems to differentiate cave types, the controls for this work were sea caves developed in Holocene eolianites, which by definition, could not contain flank margin caves of Pleistocene age, and flank margin caves near higher paleo-shorelines entered by ceiling collapse or vadose shafts, with no lateral opening to a past sea-level highstand. These end-member caves allowed qualitative comparison of diagnostic features unique to each cave type. The various measurements subsequently used were an attempt to quantify these observations.

In regard to Bill Mixon's statements, comparison of caves from differing geologic environments would certainly be expected to give different results; how they differ was the important question. In carbonate islands, one cannot tell at a glance of a cave map if a cave is a sea cave or a flank margin cave; that is precisely why the quantitative attempt was undertaken. These San Salvador caves are developed in geologically identical Quaternary eolianites, and the caves formed in geologically recent time, and can be overprinted. As a result, criteria for differentiation are subtle. The issue of dimensionless ratios is irrelevant; hydraulic radius is an area to perimeter ratio of well known effectiveness in stream hydrology.

The authors thank Mr. Erik Larson for his application and evaluation of the statistics discussed above. 